RAND RESEARCH AREAS

THE ARTS

CHILD POLICY

CIVIL JUSTICE

EDUCATION

ENERGY AND ENVIRONMENT

HEALTH AND HEALTH CARE

INTERNATIONAL AFFAIRS

NATIONAL SECURITY

POPULATION AND AGING

PUBLIC SAFETY

SCIENCE AND TECHNOLOGY

SUBSTANCE ABUSE

TERRORISM AND

HOMELAND SECURITY

TRANSPORTATION AND INFRASTRUCTURE

WORKFORCE AND WORKPLACE

This product is part of the RAND Corporation research brief series. RAND research briefs present policy-oriented summaries of published, peer-reviewed documents.

Corporate Headquarters 1776 Main Street

P.O. Box 2138

Santa Monica, California

90407-2138

TEL 310.393 .0411

FAX 310.393 .4818

(C) RAND 2007

www.rand.org

\title{
Counterinsurgency Operations May Require Modernization of the U.S. Airlift Fleet
}

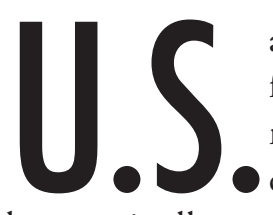

armed forces are engaged in ongoing counterinsurgency (COIN) operations ranging from the large-scale, high-intensity campaigns in Iraq and Afghanistan to many smaller missions that rarely make headlines, helping friendly governments around the world combat internal enemies. Airlift is essential in modern counterinsurgency strategies because it allows governments to deploy and support forces over long distances and facilitates efforts to extend governance and stability into remote areas. The likelihood that COIN will continue to be a major focus of U.S. national security policy has therefore revitalized debate about whether or not this type of warfare demands airlift forces with unique equipment, training, and doctrine in light of the operational contrasts between counterinsurgencies and more-conventional conflicts.

A RAND Project AIR FORCE (PAF) study of airlift requirements for COIN operations concludes that the United States should rely largely on its general airlift forces-including headquarters, units, and core aircraft types - to perform these missions. With adjustments in employment doctrines and training, these forces can accomplish the majority of COIN missions effectively. Indeed, for most missions, the tactical elements of airlift in conventional and unconventional conflicts are much the same.

However, the demands of ongoing and future COIN operations may call for substantial reinvestment and perhaps some realignment of U.S. airlift forces. Given the stress on the aging theater and battlefield airlift fleets, the day is not far off when they will require recapitalization. Moreover, COIN airlift operations present planners with some distinctive challenges that should influence the recapitalization and perhaps restructuring of the national airlift fleet. These include

- Assault airlift. COIN airlift planners need the ability to support forces in dispersed operations, nation-building activities, and relief missions in areas beyond the efficient reach of helicopters and where developed airfields are not available. If new technologies, such as satellite-guided parachute systems, cannot meet this need, it may be desirable to acquire limited numbers of fixed-wing airlifters that are smaller than current types. Any such program should emphasize capabilities for short takeoff and landing from rough fields and high survivability over other design goals, such as cargo capacity and economy of operation.

- Urban warfare. For the moment, rotary-wing aircraft remain viable for the close-in delivery of people and materiel to small units fighting in cities. But helicopters may not have sufficient survivability to remain viable in future urban-based conflicts of any type.

- Foreign Internal Defense (FID) program. Core U.S. airlifters, such as the C-17 and even the C-130, usually exceed the operational needs and logistics capabilities of small nations that receive FID support. If the FID program is to provide optimal airlift advice and support to such countries, the Air Force may wish to incorporate one or more "FID-friendly" aircraft types into its own force structure and into those of partner air forces and to develop corresponding infrastructure to maintain and support them. 


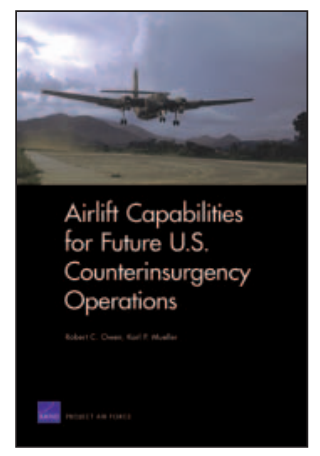

This research brief describes work done for RAND Project AIR FORCE and documented in Airlift Capabilities for Future U.S. Counterinsurgency Operations, by Robert C. Owen and Karl P. Mueller, MG-565-AF (available at http://www.rand.org/pubs/monographs/ MG565/l, 2007, 88 pp., ISBN: 978-0-8330-4038-1. The RAND Corporation is a nonprofit research organization providing objective analysis and effective solutions that address the challenges facing the public and private sectors around the world. RAND's publications do not necessarily reflect the opinions of its research clients and sponsors. RAND ${ }^{\circledR}$ is a registered trademark.

\section{RAND Offices}

Santa Monica, CA • Washington, DC • Pittsburgh, PA • Jackson, MS • Cambridge, UK • Doha, QA 


\section{RAND PROJECT AIR FORCE}

THE ARTS

CHILD POLICY

CIVIL JUSTICE

EDUCATION

ENERGY AND ENVIRONMENT

HEALTH AND HEALTH CARE

INTERNATIONAL AFFAIRS

NATIONAL SECURITY

POPULATION AND AGING

PUBLIC SAFETY

SCIENCE AND TECHNOLOGY

SUBSTANCE ABUSE

TERRORISM AND HOMELAND SECURITY

TRANSPORTATION AND

INFRASTRUCTURE

WORKFORCE AND WORKPLACE
This PDF document was made available from www.rand.org as a public service of the RAND Corporation.

This product is part of the RAND Corporation research brief series. RAND research briefs present policy-oriented summaries of individual published, peerreviewed documents or of a body of published work.

The RAND Corporation is a nonprofit research organization providing objective analysis and effective solutions that address the challenges facing the public and private sectors around the world.

\section{Support RAND}

Browse Books \& Publications

Make a charitable contribution

For More Information

Visit RAND at www.rand.org

Explore RAND Project AIR FORCE

View document details
Limited Electronic Distribution Rights

This document and trademark $(s)$ contained herein are protected by law as indicated in a notice appearing later in this work. This electronic representation of RAND intellectual property is provided for noncommercial use only. Permission is required from RAND to reproduce, or reuse in another form, any of our research documents for commercial use. 